\title{
Developing Students' Information Skills based on Empowering 8 Information Literacy Model in The Siyabalanduwa Educational Zone, Sri Lanka
}

\author{
P G Pemadasa, \\ Senior Lecturer, National Institute of Library \& Information Sciences, University of Colombo, \\ Sri Lanka e-mail: prem@nilis.cmb.ac.lk
}

\section{Prasanna Ranaweera,}

Director, National Institute of Library \& Information Sciences, (NILIS) University of Colombo, Sri Lanka e-mail: prasanna@nilis.cmb.ac.lk

Abstract: According to the statistics of the Examination Department in Sri Lanka, Monaragala is one of the lowest ranked educational zones of the at the General Certificate in Education (Advanced Level) Examination which is the final examination in school education. Siyabalanduwa division, a rural area located about $280 \mathrm{~km}$ away from the the capital of Colombo, has been obtaining the lowest rank in this examination during each year. Therefore, the researchers decided to carry out an action research as a pilot program, with the collaboration of principals, instructors and school librarians in this education division in order to remedy the above problem. Nine schools which were conducting courses of instructions for the advanced level examination in this division, were chosen for the research. Initially, a three day workshop was conducted for a group of 40 members which included principals, three advanced level teachers of the science, arts, and commerce streams and the school librarians. The concepts of information and learning, resource based learning, information literacy, empowering 8 information literacy model and information literacy skills were discussed during the first two days. The method of carrying out an action research was presented on the final day. As an outcome of this action research, each school decided to conduct a one month information literacy orientation program for newcomers to the advanced level classes. To identify the students' prior knowledge, a common written paper was applied as a pre-test. After analyzing the students' answer scripts, each school prepared an action plan which was conducted using the school library, audio visual room, and the computer laboratory, as a collaborative teaching learning process. Apart from that the NILIS research team conducted another three day workshop. On the First two days the research team 
visited each school and perused the students' pre and post test marks, lesson plans, activity sheets, student work, and written reflections. In addition, discussions were held with each school principal, teacher, school librarian and the students participating in the research. On the final day writing an action research report was introduced. After conducting the action research, each school submitted its report to the National Institute of Library \& Information Sciences (NILIS) and the Director of the Zonal Education Office, Monaragala. On analyzing the reports, it was perceived that there was a considerable improvement between pre and post test marks in each school. The students' reflections too elaborated the importance of this program for their future studies. In 2016 the Zonal Education office conducted a two day conference for all advanced level school teachers, and school librarians in the Monaragala District promote this program as a solution for the problem.

Keywords: Students' Information Skills, Empowering 8 Information Literacy Model, Information literacy

\section{Introduction}

\section{Sri Lankan school system}

Sri Lanka is an island divided into nine provinces and twenty- five districts. There are ninety -three education zones, three hundred and four education divisions and nine thousand six hundred and sixty- two schools scattered island wide, which are administered by the Ministry of Education. The total student population is 3,929,234. Table 1 elaborates this distribution. (Ministry of Education 2008)

Table 1: Education administrative system in Sri Lanka

\begin{tabular}{|c|c|c|c|c|c|}
\hline Province & $\begin{array}{c}\text { No. of } \\
\text { Districts }\end{array}$ & $\begin{array}{c}\text { No. of } \\
\text { Education } \\
\text { Zones }\end{array}$ & $\begin{array}{c}\text { No. of } \\
\text { Education } \\
\text { Divisions }\end{array}$ & $\begin{array}{c}\text { Number } \\
\text { of } \\
\text { Students }\end{array}$ & $\begin{array}{c}\text { Number } \\
\text { of } \\
\text { Teachers }\end{array}$ \\
\hline 1. Western & 3 & 11 & 38 & 940,393 & 42,013 \\
\hline 2. Central & 3 & 15 & 39 & 525,594 & 30,960 \\
\hline 3. Southern & 3 & 11 & 39 & 509194 & 28,679 \\
\hline 4. Northern & 5 & 12 & 33 & 247,726 & 14,637 \\
\hline 5. Eastern & 3 & 13 & 44 & 388,222 & 20,486 \\
\hline 6. North Eastern & 2 & 8 & 31 & 473.642 & 27,394 \\
\hline 7. North Central & 2 & 8 & 30 & 265,490 & 14,878 \\
\hline 8. Uva & 2 & 8 & 23 & 274,815 & 18,962 \\
\hline 9. Sabaragamuwa & 2 & 7 & 27 & 371.905 & 21779 \\
\hline
\end{tabular}


The Sri Lankan school education system is divided into four major stages. They are Primary, Junior Secondary, General Certificate in Education (Ordinary Level) (G.C.E.O/L) and the General Certificate in Education (Advanced Level) (G.C.E.A/L) stages. The students' achievement levels are nationally measured at three stages; the Grade Five Scholarship examination, G.C.E (O/L) and G.C.E (A/L) Examinations, by the Department of the Examination (DoE) Sri Lanka.

Table 2: School Grades and Examinations

\begin{tabular}{|l|c|c|}
\hline \multicolumn{1}{|c|}{ Stage } & Grade & Examination \\
\hline 1. Primary & 1 to 5 & Grade five Scholarship \\
\hline 2. Junior Secondary & 6 to 9 & - \\
\hline $\begin{array}{l}\text { 3. Senior Secondary } \\
\text { G.C.E. (Ordinary Level) }\end{array}$ & 10 to 11 & G.C.E. (O/L) \\
\hline $\begin{array}{c}\text { 4. Senior Secondary } \\
\text { G.C.E. (Advanced Level) }\end{array}$ & 12 to 13 & G.C.E. (A/L) \\
\hline
\end{tabular}

The G.C. E. A/L examination is the final stage of school education. After the G.C.E (A/L) examination, students are selected for university education or vocational and technical education. 'At the G.C.E A/L examination approximately 60 percent of students reach the pass level, but only about 15 percent of these are selected to the universities. This has made the examination extremely competitive and students seek private tuition to obtain very high marks. Therefore, the G. C. E. A/L stage is a very competitive and crucial stage in the Sri Lankan education system and the students pay more attention to the cramming of facts, than to acquiring competencies'.

As a result, students engaged in the remembering, understanding, and applying stages as surface learners, instead of engaging in the analyzing, evaluating and creating stages as deep learners. Therefore, these students obtain a lower achievement level in any examination, especially those in rural areas obtain lower achievement levels at the G.C.E. $(\mathrm{A} / \mathrm{L})$ Examination, than those in urban and semi-urban areas.

\section{The School library system}

When considering the Sri Lankan school library system, according to the educational reforms implemented by the Ministry of Education (MoE) in 1998, with the assistance of the World Bank, special attention was paid to convert the traditional school library into a school library learning resource center for the enhancement of quality teaching and learning. To accomplish this goal the MoE implemented various measures. The initial step was to 
establish the School Library Development Unit (SLDU) within the MoE, as a new concept for developing island - wide school library programs. Also an assistant director of education (school library) was appointed for each province and each zone of education. They are the officers responsible for planning, monitoring, and evaluating of the school library programs of each province and zone.

In addition to that, two thousand new school libraries were built, and two thousand existing libraries were renovated. The name of the school library was changed to School Library Learning Resource Centre (SLLRC) which is the combination of three units in the school system; the library, audio- visual room, and computer room. Parallel to this task, four thousand graduates were appointed as teacher librarians to the island - wide school system and the National Institute of Library \& Information Sciences (NILIS) were established under the Univeristy of Colombo, within the university premises to provide professional qualifications for the above cohort.

\section{Empowering 8 Information Literacy Model}

In 2004 IFLA-ALP and NILIS jointly organized a five - day international workshop in Colombo to promote information literacy for learning in the South and South East Asian countries. The output of the workshop was an eight step model, Empowering 8, as a novel information literacy model in the field.

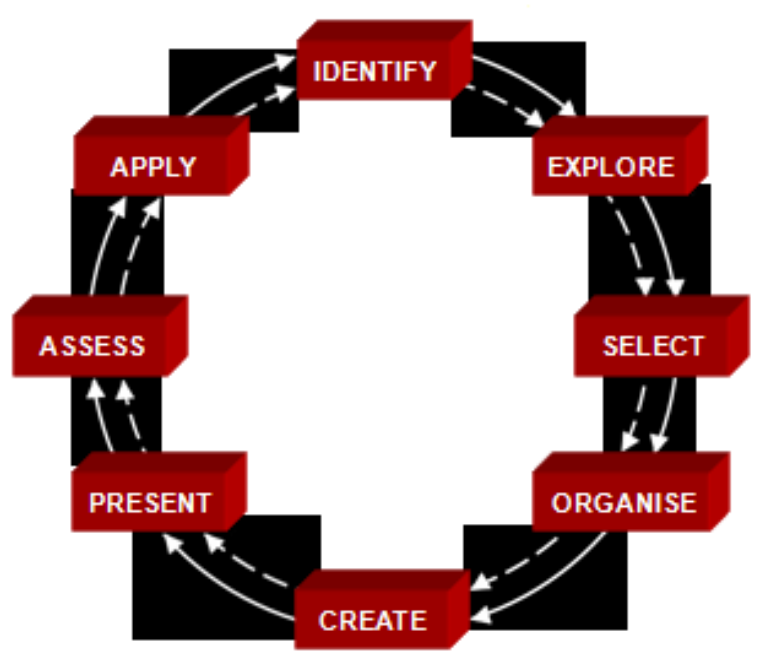


Figure 1 Empowering 8 Information Literacy Model

After the formulation of this model in 2005, NILIS introduced it to the school and university system as a teaching - learning model with the patronage of the University Grants Commission (UGC) and the Ministry of Education in Sri Lanka.

\section{Problem Statement}

Since 2005, NILIS has been conducting lectures, workshops, seminars, providing trainers for training programs and general and subject- related reading camps, school - based staff development programs and also national and provincial level conferences, based on the Empowering 8 Model, to uplift the information literacy skills in the school education system island wide. However, a formal agenda related to the information literacy subject could not be implemented in the school education system by the MOE.

In 2013, the MoE was split into two Ministries, viz the Ministry of Education and the Ministry of Education Services. As a result, the SLDU was established under the Ministry of Education Services. The main duty of the SLDU was providing physical resources for school libraries. Because of that, a formal policy regarding the introduction of IL programs island wide could not be achieved. However, NILIS conducted IL programs, informally, at the invitation of several provinces and zones, within the budget allocated for the school library vote. In the above backdrop, students and teachers in general, engage in their teaching and learning process without a formal information literacy awareness program.

When translating the English term 'information literacy' into Sinhala or Tamil languages in general education, it provides related meanings such as information competency and information fluency. This is because the Sri Lankan general education reforms are based on Seven Basic Competencies, (i) Competencies in communication: (ii) Competencies relating to personality development (iii) Competencies relating to the environment (iv) Competencies relating to preparation for the world of work (v) Competencies relating to religion and ethics (vi) Competencies in play and use of leisure (vii) Competencies relating to 'learning to learn' and competency - based learning process. (Ministry of Eduaction (2013)

On the other hand, research reveals that 'the G.C.E. A/L stage is a very competitive and crucial stage in the Sri Lankan education system and students are more concerned with cramming of facts rather than acquiring competencies'. This evidence elaborates a mismatch between basic competencies and information competency regarding the G.C.E.A/L stage. As a result, 'Sri Lanka has managed to achieve high levels of literacy; it has been unable to provide students with high - quality educational service.' (Liyanage, K. 
2015). It means, that the teaching - learning process does not centralized on resource, project, problem and inquiry - based leanings. Therefore, introducing a separate information skills development program for general education in Sri Lanka is essential to minimize this situation.

According to statistic of the Department of Examinations in Sri Lanka, the rural districts such as Mannar, Mulathive, Kilinochi, Monaragala and Polonnaruwa are the lowest ranking districts on the results of the G.C.E. (A/L) examination. Therefore, NILIS submitted a project proposal to the University of Colombo to introduce a formal IL program for the Northern Province and Uva Province of Sri Lanka, which was approved. This study focuses on developing information skills for the grade 12 students in the Siyabalanduwa Education Division in the Uva province. The researchers selected schools conducting $A / L$ classes in the Siyabalanduwa Educational Division in the Monaragala District, which is located beyond 280 kilometers away from the Colombo city, to implement this division wide action research program, with the collaboration of the divisional education director, principals, $A / L$ teachers and teacher librarians in this educational division.

\section{Literature review}

The concept of information literacy consists of three components such as Information skills, generic skills and values and beliefs. "Generic skills include problem solving, collaboration and teamwork, communication and critical thinking. Information skills include information seeking, information use and information technology fluency. Values and beliefs include using information wisely and ethically, social responsibility, and community participation". Bundy, Alan 2004.

When combining the above three segments with teaching any subject area in school education, students could develop their information literacy skills and gradually become independent and lifelong learners. In order to accomplish this goal, the Empowering 8 (E.8) information literacy model provides the proper road map to reach the destination. This study has been conducted as an action research. Hine (2013) Explains action research as follows "Historically, the term 'action research' has been long associated with the work of Kurt Lewin, who viewed this research methodology as cyclical, dynamic, and collaborative in nature. Through repeated cycles of planning, observing, and reflecting, individuals and groups engaged in action research can implement changes required for social improvement" 


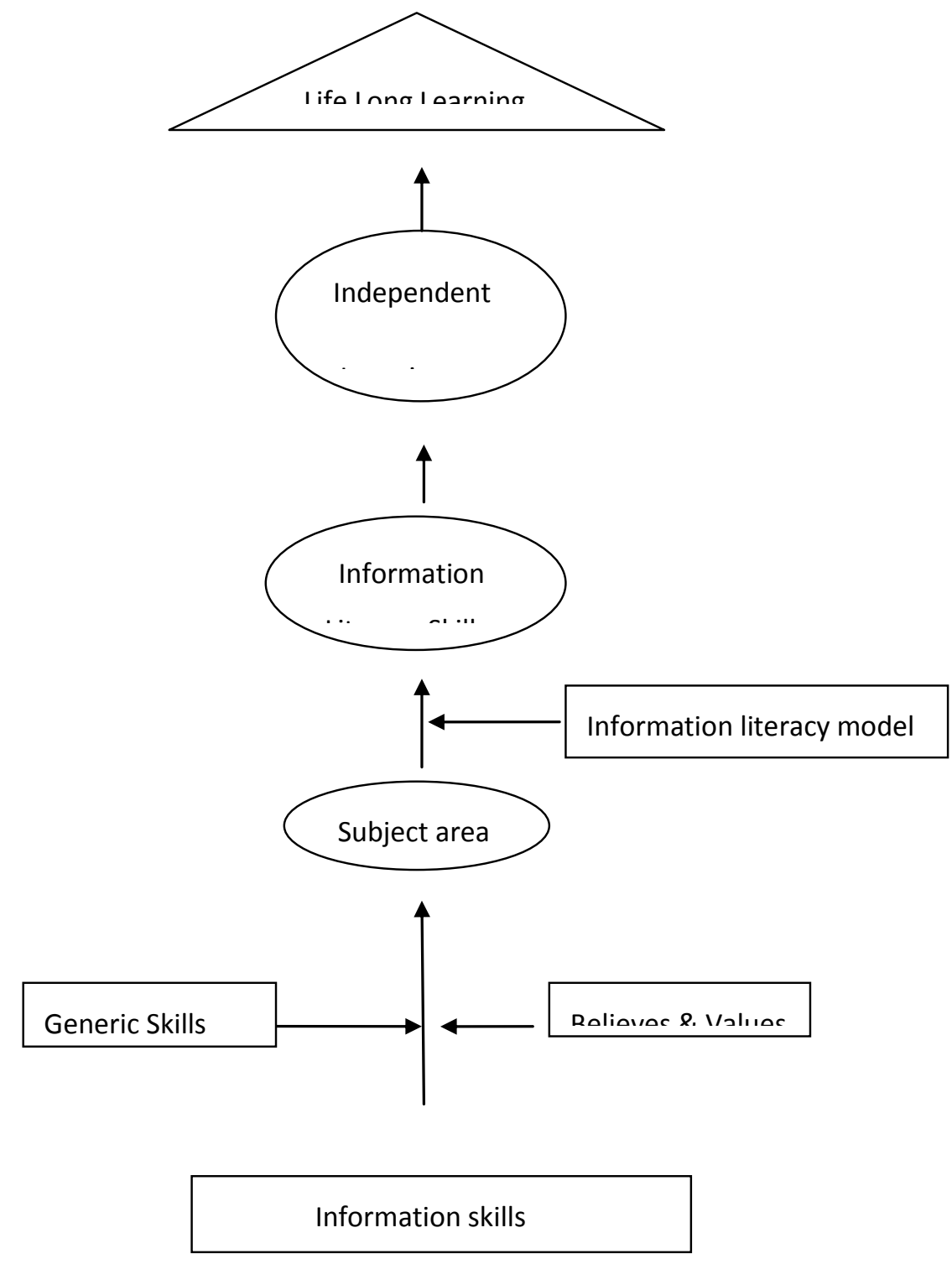

Figure 2: Information Skills to Life Long Learning

Before engaging in an Information literacy program based on Empowering 8 Model, students need to be competent in information skills under each stage. 


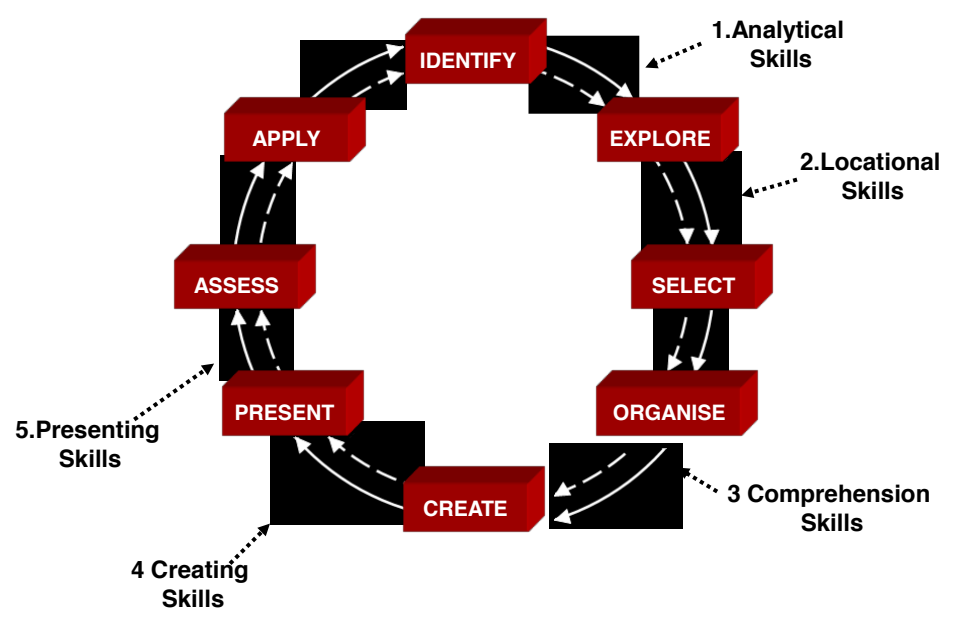

Figure 3 Empowering 8 and related skills

Table: 2 Stage and type of Information skills

\begin{tabular}{|c|c|}
\hline Stage & Type of information skills \\
\hline - Identify & - Analytical skills \\
\hline - Explore & - Location skills (printed and electronic) \\
\hline - Select and organize & - Comprehension skills \\
\hline - Create & - $\begin{array}{l}\text { Reporting } \\
\text { electronic) }\end{array}$ skills $\quad$ (printed \\
\hline - Present & - Presentation skills \\
\hline
\end{tabular}

According to the theoretical perspective about Blooms' Revised Taxonomy, students who engage in the remembering, understanding and applying stages are the surfaces learners. However, if they move to analyzing, evaluating, and creating, the upper stages of this taxonomy, they can be deep learners. To convert this theory into practice the IL model is essential. Figure 4 demonstrates that combination. 

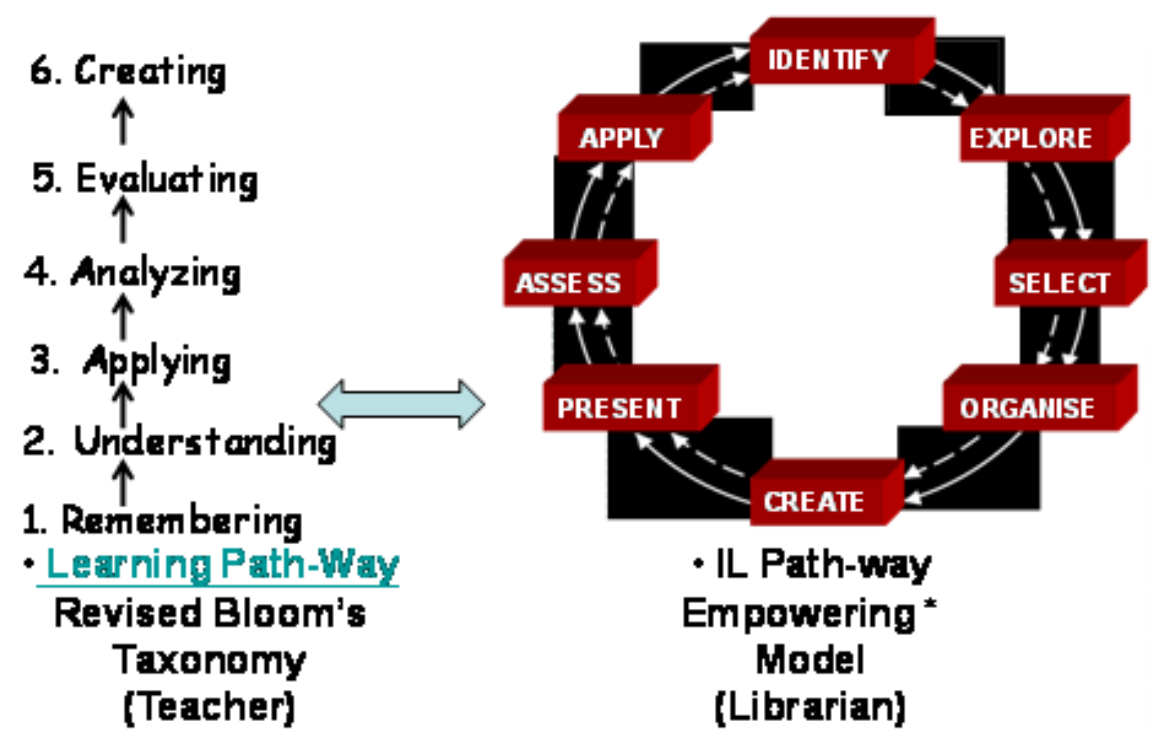

Figure 4: Process of Learning

When using this model for the teaching learning process, the students need to apply the above information skills to complete their tasks. The subject teachers and teacher librarian collaboration is essential to fulfil the students' achievement level. The double arrows of the cycle indicate that phenomena. This research focuses on developing information skills under each stage of E.8 model.

\section{Research Questions}

As staff members of the National Institute of Library \& Information Sciences, focusing on information literacy in general education in Sri Lanka, the researchers needed to develop information skills that could be transferred to the classroom subjects of the $A / L$ students, in the Siyabalanduwa Education Division. As a result, students could gradually reach the information literacy skill level, which would empower them to engage in independent learning or learning how to learn. The net result would be obtaining a higher achievement level at the G.C.E.A/L examination. This background led to the under mentioned action research questions.

- What is the difference between information skill and information literacy skill?

- Why should an information literacy model be introduced for developing the therapeutic stage in this action research? 
- What is the impact of the six week orientation program at the grade twelve students' achievement of information skills?

- How effective has the Empowering 8 information Literacy Model has been in improving the students' projects and assignments?

\section{Objectives}

The main objective of the study was to find out the effect of using Empowering 8 Information Literacy Model for developing the students' information skills. To accomplish this, the following sub - objectives were identified

1. Introduce an information literacy awareness program based on Empowering 8 Model for selected principals, teachers and teacher/school librarians in the Siyabalanduwa Education Division.

2. Identify the students' prior knowledge related to information skills under Empowering 8 Information Literacy Models, of selected A/L students in the above area.

3. Develop a six - week action plan to solve the above- identified issues.

4. Design and implement the six weeks Information skills orientation program for advanced level students in each school.

5. Evaluate the first cycles of the completed division - wide action research program.

6. Provide conclusions and suggestions.

\section{Methodology}

Nine schools conducting $\mathrm{A} / \mathrm{L}$ classes in the Siyabalandua division of education were selected for this division wide action research. The following table shows the distribution of the students in selected schools

Table 3: distribution of the students in selected schools

\begin{tabular}{|c|c|c|c|c|c|}
\hline Name of the school & Maths stream & $\begin{array}{c}\text { Science } \\
\text { stream }\end{array}$ & $\begin{array}{c}\text { Commerce } \\
\text { stream }\end{array}$ & Arts stream & Total \\
\hline
\end{tabular}




\begin{tabular}{|l|c|c|c|c|c|}
\hline $\begin{array}{l}\text { 1. Siyabalanduwa } \\
\text { Maha Vidyalaya }\end{array}$ & - & - & 11 & 42 & 52 \\
\hline 2.Etimale M.V & 02 & 05 & 08 & 46 & 61 \\
\hline $\begin{array}{l}\text { 3. Dobagahaela } \\
\text { Secondary school }\end{array}$ & 03 & 10 & 11 & 96 & 120 \\
\hline 4 Galabedda. M. V & - & - & - & 22 & 22 \\
\hline $\begin{array}{l}5 \text { Kandaudapanguwa. } \\
\text { Vidyalaya }\end{array}$ & - & - & - & 08 & 08 \\
\hline 6 Hathare kanuwa M.V & 02 & 04 & - & 24 & 30 \\
\hline $\begin{array}{l}\text { 7 Palaewela Secondary } \\
\text { school }\end{array}$ & - & - & - & - & 03 \\
\hline 8 Buddama.M.V & - & - & - & - & 13 \\
\hline 9 Vilaoya Sripali M.V & & & & & \\
\hline
\end{tabular}

A forty member group comprising the principal of each school, three $A / L$ teachers from the science, arts and commerce streams of each school and the school librarian, were selected for the sample. Apart from that the Siyabalanduwa divisional director of education, and the library and ICT in-service advisers were included in the sample. Firstly, the researchers introduced a three - day workshop for this sample utilizing the school library, audiovisual and computer laboratory of the Siyabalnduwa National School. On the first two days, concepts of information, information skills, resource based learning, information literacy, Empowering 8 information literacy model and information literacy skills were discussed with the research participants. On the final day, action research principles and the method of conducting an action research were introduced. As a result, each school decided to conduct an action research for the new comers to the $A / L$ classes in 2015 . The school principal provided the leadership to his/her school research team to continue this research and the divisional director of education and two in-service advisors acted as coordinators of the research. In addition to that, the researchers monitored the action research program of each school based on distance mode, using telephone, e -mail and Google apps. The research team of each school prepared a pre - test to identify their students existing information literacy skills related to library skills, computer literacy, audio- visual skills and internet literacy. After analyzing all the pre test papers, a common written diagnostic test, including forty questions was prepared for this division wide action research, as follows. The time duration was three hours.

Table 4: Skills category and types of questions

\begin{tabular}{|l|c|c|}
\hline \multicolumn{1}{|c|}{ Category } & $\begin{array}{c}\text { No. of } \\
\text { Questions }\end{array}$ & Types of Question \\
\hline 1. Library skills & $1-10$ & Structured \\
\hline 2. Computer literacy & $11-20$ & Structured \\
\hline
\end{tabular}




\begin{tabular}{|l|c|c|}
\hline 3. Audio visual skills & $21-28$ & Structured \\
\hline 4. Internet literacy & $29-38$ & Structured \\
\hline $\begin{array}{l}\text { 5. Writing an essay (250 } \\
\text { words) }\end{array}$ & 39 & Essay \\
\hline $\begin{array}{l}\text { 6.Describe the pre } \\
\text { preparation procedure } \\
\text { about the essay }\end{array}$ & 40 & Essay \\
\hline
\end{tabular}

To identify the students' information literacy skills, each school applied the common written diagnostic test paper as a pre test. After analyzing the students' answer scripts, each school prepared its action plan which was submitted for editing to the divisional education office and NILIS. After the plans were edited, each school research team, subject teachers and school librarian, implemented the plan based on resource based teaching, using the school library, audio visual room and computer laboratory. The action plan demonstrated a collaborative teaching- learning process and students engaged in their activities focusing on resource -based learning. The school principal provided the leadership to continue this program.

Table 5: Empowering 8 IL Skills and description

\begin{tabular}{|c|c|c|c|c|}
\hline Place & $\begin{array}{l}\text { Stages of } \\
\text { E. } 8\end{array}$ & $\begin{array}{c}\text { Information } \\
\text { skills }\end{array}$ & Description & $\begin{array}{c}\text { Time } \\
\text { Duration }\end{array}$ \\
\hline 1. Classroom & Identify & $\begin{array}{l}\text { Analytical } \\
\text { skills }\end{array}$ & $\begin{array}{l}\text { - Mind Mapping } \\
\text { - Concept Mapping } \\
\text { - } 5 \mathrm{WH} \text { Technique }\end{array}$ & First week \\
\hline 2. Library & Explore & $\begin{array}{l}\text { Location } \\
\text { skills }\end{array}$ & $\begin{array}{l}\text { - Identify the library } \\
\text { collection } \\
\text { - Parts of a book } \\
\text { - Use color system or card } \\
\text { catalogue } \\
\text { - Use color system or card } \\
\text { catalogue } \\
\text { - Follow DDC } \\
\text { - Select the relevant book } \\
\text { using the call number } \\
\text { - Open the relevant page } \\
\text { using the book index }\end{array}$ & $\begin{array}{l}\text { Second } \\
\text { week }\end{array}$ \\
\hline 3. Computer unit & Explore & $\begin{array}{l}\text { Location } \\
\text { skills }\end{array}$ & $\begin{array}{l}\text { - Ms Word \& PowerPoint } \\
\text { - How to access to the } \\
\text { internet' } \\
\text { - Anatomy of a URL } \\
\text { - Types of search engines } \\
\text { - Select the best search } \\
\text { engines. } \\
\text { - Using Google effectively } \\
\text { - Evaluating web sites } \\
\text { (AAOCC Model) }\end{array}$ & Third week \\
\hline
\end{tabular}




\begin{tabular}{|c|c|c|c|c|}
\hline 4. Library & $\begin{array}{l}\text { Select } \\
\text { organize }\end{array}$ & $\begin{array}{l}\text { Comprehe } \\
\text { nsion skills }\end{array}$ & $\begin{array}{l}\text { - How to use an } \\
\text { encyclopedia } \\
\text { - How to use a dictionary } \\
\text { - SQ3R reading method } \\
\text { - Note taking and note } \\
\text { - Making } \\
\text { - Map reading } \\
\text { - Picture reading } \\
\text { - } \text { Graphic organizers }\end{array}$ & $\begin{array}{l}\text { Fourth } \\
\text { week }\end{array}$ \\
\hline 5. Audio visual unit & Create & $\begin{array}{l}\text { Reporting } \\
\text { skills }\end{array}$ & $\begin{array}{l}\text { - Editing } \\
\text { - } \text { Citations } \\
\text { - Proof reading } \\
\text { - Make overhead } \\
\text { - } \text { transparencies } \\
\text { - PowerPoint presentation }\end{array}$ & Fifth week \\
\hline 6. Audio visual unit & Present & $\begin{array}{l}\text { Presentatio } \\
\text { n skills }\end{array}$ & $\begin{array}{l}\text { - Oral presentation } \\
\text { - PowerPoint presentation } \\
\text { - OHP presentation }\end{array}$ & Final week \\
\hline
\end{tabular}

The research team of each school evaluated the completed activities of the students examining their notes, journals, photos, assignments, practical work and artifacts and provided the feedback for the students. The program was monitored and assessed by the principal of each school, In-service advisers and divisional director of education. After completing the action research, the pre test was given as the post to identify the new situation about the students' information skills competencies.

Apart from that, the NILIS research team conducted another three day workshop for the final evaluation of this division wide action research program. On the first two days the research team spent two hours in each school. During those two hours they discussed with the principal, , school librarian and teachers and students participating in the research and observed their pre and post test marks, lesson plans, activity sheets, students' work and their written reflections. On the final day each school was given 15 minutes to present their completed presentations to the audience using ms power point. The presentations were evaluated by the researchers using a prepared rubric, who also introduced how to write an action research report.

After a month, each school submitted its action research report to the NILIS and Director of the Zonal Education Office Monaragala. When analyzing the reports, it was observed that there was a considerable improvement between the pre and post test marks in each school, and the students' reflections provided the importance of this program for their future studies. The Zonal education office was willing to conduct a two - day conference for all $A / L$ school teachers and school librarians in the Monaragala District to promote this Information literacy program as a remedy for the above stated problem. 


\section{Data gathering and analyzing procedure}

Data was gathered by observing, inquiring and examining by the three teams, which were the school research team, evaluating and monitoring team, and the researchers. The school research team observed the whole process as participant observers and nine school principals observed this program as external observers. The following six categories were applied as the data analysis procedure.
A. Pre and post test marks
B. Students' reflections
C. Participant teachers' reflections
D. Principals' reflections
E. Coordinators'reflections
F. Evaluating research projects

\section{A. Pre and post test marks}

Firstly, the students faced the three hour common written examination as a pre test which was prepared with the contribution by each school research team and finally edited by the monitoring team and the NILIS researchers. The mean value of the pre test and post test of the first cycle of this action research as follows

Table 6: The mean value of the pre test and post test

\begin{tabular}{|l|c|c|c|}
\hline \multicolumn{1}{|c|}{ School } & $\begin{array}{c}\text { Pre -test mean } \\
\text { value }\end{array}$ & $\begin{array}{c}\text { Post- test mean } \\
\text { value }\end{array}$ & Difference \\
\hline $\begin{array}{l}\text { 1. } \\
\text { Siyabalanduwa } \\
\text { Maha Vidyalya }\end{array}$ & 24.3 & 70.5 & 46.2 \\
\hline $\begin{array}{l}2 . \text { Budddama Maha } \\
\text { Vidyalaya }\end{array}$ & 53.7 & 80.4 & 26.7 \\
\hline $\begin{array}{l}\text { Ehtimale Maha } \\
\text { Vldyalaya }\end{array}$ & 28.3 & 68.4 & 40.1 \\
\hline $\begin{array}{l}\text { 4.Galabedda Maha } \\
\text { vidyalaya }\end{array}$ & 20.3 & 62.2 & 46.9 \\
\hline $\begin{array}{l}\text { 5. Dobagahawella } \\
\text { National School }\end{array}$ & 26.2 & 72.2 & 48.7 \\
\hline $\begin{array}{l}6 . \text { Haterekanuwa maha } \\
\text { vidyalaya }\end{array}$ & 21,5 & 70.2 & 53.0 \\
\hline $\begin{array}{l}\text { 7. Kandaudapanguwa } \\
\text { Maha Vidyalaya }\end{array}$ & 23.2 & 76.2 & 48.2 \\
\hline 8. Palewella Maha & 25.8 & 74.4 & \\
\hline
\end{tabular}




\begin{tabular}{|l|c|c|c|}
\hline Vidyalaya & & & \\
\hline $\begin{array}{l}\text { 9.Vilaoya } \\
\text { Vidyalaya }\end{array}$ & 19.5 & 72 & 53.5 \\
\hline
\end{tabular}

The above quantitative analysis showed a positive improvement in the mean values of the post - test marks of the students after the implementation of the action research. The values of the mean differences, after the implementation of the action research program confirm that the students' information skills have developed based on the empowering eight information literacy model.

Apart from the above quantitative analysis, the following qualitative analysis, reflections of students, participant teachers, principals and coordinators, also support the above inference. The written and oral reflections are given in Annexure 01.

\section{Evaluation of the action research report}

Apart from the above reflections, the action research report of the participating teachers was evaluated by the researchers. After completing the first cycle of the action research, the researchers provided one month for the schools to prepare their action research reports. Finally, seven schools out of nine submitted their reports for evaluation.

To prepare the action research reports the researchers provided a common list of instructions about the format, referencing styles, and evaluation procedure. According to an evaluation of the report following finding can be illustrated

- Calculated the differences between pre and post test marks

- Measured the positive improvement

- Provided their conclusion and suggestions

- Attached photos and students' reflection related to the action research.

All these primary sources proved that the information skills of the new comers to grade twelve in the schools of the Siyabalanduwa Education Division had developed, based on the empowering 8 information Literacy model was successful.

\section{Conclusions}

After conducting a six weeks division wide action research for the grade 12 students in the Siyabalanduwa education division the following conclusion can be made.

1. Post test marks in all schools provided the positive improvement, which indicated the success of this program 
2. Therefore, it is not necessary to continue a second cycle for this action research

3. The final presentation of the participating teachers in each school illustrated the above situation and the Empowering $8 \mathrm{IL}$ model provided proper guidelines for students to obtain information skills in any subject discipline.

4. Collaborative teaching developed the student-teacher relationship which provided the successful learning environment

5. School library, computer laboratory and audio visual center should be considered as the school learning resource center for student learning

6. Without adequate knowledge about printed and electronic information skills, engaging in deep learning is very difficult

\section{Suggestions}

After completing this action research program, the following suggestions can be made as follows.

1. After identifying the impact of the first cycle of this action research, the participant teachers can implement the second cycle for the above students as a continuing program

2. This action research program could be introduced school wide by the participant teachers because they have a thorough knowledge about conducting such a program

3 The divisional education director can organize a one day conference for all teachers in this division, focussing on this research as a basic awareness program.

4 The officers and policy makers of the Uva Province could publish this as a book and distribute it among all the schools in the Uva Province

Acknowledgments: Mr. Alahakoon, Asst Librarian, NILIS and Mr. Asitha Sandaruwan, Director, Uva Library Services Board.

\section{References:}

Bundy, Alan 2004 New Zealand Information Literacy Framework: principles, standards and practice, Adelaide Australian and New Zealand Institute for Information Literacy

Hine, G. S. C. (2013) The importance of action research in teacher education programs, Issues in Educational Research, 23 (2), 2013: Special Issue. Retrieved from

http://www.iier.org.au/iier23/hine.pdf 
Liyanage, K. 2014, Education system of Sri Lanka: strengths and weaknesses. Retrieved from http://www.ide.go.jp/Japanese/Publish/Download/Report/2013/pdf/C02 ch7.pdf

Ministry of Eduaction (2008) School Census - 2008. Preliminary Report. Retrieved from http://www.statistics.gov.lk/education/preliminaryreport-2008.pdf

Ministry of Eduaction (2013) Education first Sri Lanka. Retrieved from http://planipolis.iiep.unesco.org/upload/Sri\%20Lanka/Sri_Lanka_Education_first_2013.pdf

Rosenfeld, E. \& Loertscher, D (2007) Towards a twenty first century school library media program, The Scarecrow press, Lanham Second edition Retrieved from

http://www.caul.edu.au/content/upload/files/info-literacy/InfoLiteracyFramework.pdf

\section{Biography:}

1. P.G. Pemadasa has been working as a senior lecturer in the National Institute of library and Information science, University of Colombo, Sri Lanka since 2005. His academic background includes B.Sc. Honors, Postgraduate Diploma in Education, Master of Education, University of Colombo, Sri Lanka, Master of education (Educational Leadership) University of Wollongong, Australia. Certificate in University orientation Program, Simon Fraser and York University, Canada, Certificate In Teaching Higher Education, University of Colombo, Sri Lanka, Certificate in Information literacy trainer for training in UNESCO. His main research interest is Information literacy in school education.

2. Prasanna Ranaweera is the Director, National Institute of Library \& Information Sciences (NILIS) University of Colombo, Sri Lanka, where he has been employed since 2005 as a Senior Lecturer. Prior to joining NILIS, He was employed as an Asst. Librarian at the University of Sri Jayawardenapura and at the National Library of Sri Lanka, since 1992. His academic background includes a Masters in Library and Information Science from the University of Colombo and special training in Information Literacy from the University of Victoria, Wellington, New Zealand.

Annexure 01: written and oral reflections

After completing the research, the researchers visited each school and interviewed the principal, participant teachers and three students randomly selected. Finally, the principal 
arranged a common meeting with the participating students and teachers. Another three students provided analytical speeches about the action research program representing the student sample.

The following were the quotes in relation to such feedback from all most all students in each school using printed materials

1 "I had not an idea about how to search information from a book using an index before starting this program, but now I clearly know how doing it

2."Before participation this program I did not use printed encyclopedia for my information needs because of the unawareness about how to use it. But our research team teachers provided guidelines for us to how to use encyclopedias as a guided discovery method"

3. "Earlier I used the English, Sinhala dictionary without knowing any awareness, I did not follow guide words when searching a meaning of a word and did not concern about abbreviations and parts of speech of a dictionary"

4. "Now I clearly know the parts of a book and the importance of the each part"

5 "I saw some numbers and letters on the spine of my school library books, and I realize that it helps only library staff. But now I understood, which is the call numbers and author's short names to find books from the library for users"

All these quotations emphasize that without having these basic information skills related to printed materials, students were engaged in learning which was a surface or route learning that would directly effect for their low achievement level in any examination.

C. Participant teachers' reflections

The researchers went to this area and spent three days in evaluating the program. First two days we visited each school and observed and interviewed. Final day each school research participant teachers displayed their effort using 15 minutes PowerPoint presentation.

Following are the major quotations

"This program provided the new experience for students and all students participated in enthusiastically. Because we provided for student for engaging in activity based, computer based, internet based and inquiry based learning opportunities"

"In our normal classroom teaching, we used isolated teaching, but in here we practiced with collaborative teaching with our teacher librarian and us identified the benefit of collaborative teaching for students' learning, 
"After completing this program, we realized that without having proper awareness about information skills related to the printed and electronic media learning is utter failure"

This reflection demonstrated the participant teachers' previous teaching styles. It did not support for students deep learning and it is also a deeply affect for students' lower achievement level in any examination

Principal's observation

Grade 12 students in nine schools participated in this division wide action research program and each school principal provided the leadership to implement this program. Before and after implementing the program, the researchers discussed with each principal engaged in the program. The following quotes emphasize their reflections

$\mathrm{P} 1$ :Before starting this program I obtained an awareness about information, information skills, information literacy, resource based learning, Empowering 8 Model and independent learning our NILIS lecturers. Selected three A/L teachers, teacher Librarian and I prepared our action plan explained the program objectives for our $13 \mathrm{~A} / \mathrm{L}$ students. When analyzing the students' pre test marks we astonished about the student's poor achievement level. But this was not our students' fault because they have not formal agenda for developing information skills within our school curriculum. However NILIS Introduced a formal strategy for us to implement this for our students learning process

P2: Fifty two Students participated in this program. During the whole program, students were actively involved in those activities using our school computer laboratory, audio visual center and library. Earlier I could not see this kind of program in my school using the above centers. Participant teachers paid a special attention for students' work This was a new experience for me as a principal for introducing IL program whole school

P3: Hundred and twenty students (maths,Science.commerce.and art streams) participated in this program. My school is one of the leading schools in this division. After comparing the pre and postmarks we saw a considerable positive improvement of the achievement level of information skills. As a result, it built up a good teacher student relationship and students highly appreciated this program's behalf of their future studies

\section{Coordinators reflections}

The divisional education director and two in-service advisors have coordinated this division wide action research. The following reflections were provided by them. 
1. According to my observations and discussions, this program was very successful. Because my education division is situated in a very remote area and most of the parents living conditions are poor. But schools have sufficient facilities. Therefore, these kinds of programs are highly helpful not only for students but also teachers. During this action research period participated teachers clearly demonstrated how to apply collaborative teaching and resource based teaching. I think, if we continue this program as a school wide action research, we could obtain successful achievement levels in any examination

2. As an in-service advisor. I have visited the nine schools before and during this action Research period. Participating teachers and students engaged in those activities very enthusiastically. Before this research, I saw solitary libraries and audio visual rooms. But during last two months, the above units filled with students and provided a joyful classroom environment and instead of traditional lectures I saw inquiry and activity based learning engagements and the E.8 model provided a proper path -way for it 